\title{
Knowledge Management practices: Teachers perception
}

\author{
Mr. Muhammad Ayoob Khan Babar
}

Research Scholar, Department of Education, International Islamic

University, Islamabad

Prof. Dr. N. B. Jummani

Dean Faculty of Social Sciences, International Islamic University, Islamabad

Dr. Sheikh Tariq Mahmood

Department of Education, International Islamic University, Islamabad

\section{Mr. Sufi Amin \\ Hafeez Uddin}

Research Scholar, Department of Education, International Islamic

University, Islamabad

doi: 10.19044/esj.2016.v12n25p365 URL:http://dx.doi.org/10.19044/esj.2016.v12n25p365

\begin{abstract}
In today's world, Knowledge Management is considered as a key to organizational growth and competitiveness. This study aim was to investigate the perception of teachers about main factors affecting the teaching learning process in adopting and applying Knowledge Management. The main objectives of the study were (i) to explore the existing Knowledge Management Practices of teachers in International Islamic University Islamabad (ii) to find out the difficulties regarding knowledge management and (iii) to examine the factors affecting the application of Knowledge Management Practices in improving the performance of teachers. Qualitative method was used as mode of inquiry. Data was collected through an Interview guide. Concurrent exploratory design was used in the study while collecting and analyzing data. Qualitative data was analyzed through content analysis and percentage.
\end{abstract}

Keywords: Knowledge Management, Knowledge creation, Knowledge sharing

\section{Introduction}

The ability to manage knowledge is crucial in today's knowledge economy. The creation and diffusion of knowledge have become increasingly important factors in competitiveness. Knowledge management is a process that transforms individual knowledge into organizational knowledge. The 
knowledge management $(\mathrm{KM})$ can be defined as the systematic coordination of people, technologies, processes and organizational structure in order to add value to the organization through the reuse of knowledge and innovation. This coordination can be achieved by way of the creation, sharing and application of knowledge (Dalkir, 2005).

The competitive edge of individuals, enterprises, and even nations has increasingly become dependent on their ability to apply knowledge and leverage it in a continuous way (Dimitriades 2005). In accordance with the knowledge-based view (hereafter referred to as KBV) of the firm (Grant 1996), managing knowledge-based resources has become the key for sustaining a CA and superior performance. To understand Knowledge Management, one must understand knowledge, Knowledge Management process (Grover \& Davenport 2001).

\section{Knowledge}

Knowledge is often defined as a "justified personal belief." Alavi and Leidner (2001) define knowledge as "knowledge is information possessed in the mind of individuals: it is personalized information (which may or may not be new, unique, useful, or accurate) related to facts, procedures, concepts, interpretations, ideas, observations, and judgments.". There is much taxonomy that specifies various kinds of knowledge. The most fundamental distinction is between "tacit" and "explicit" knowledge. (Alavi \& Leidner, 2001). Knowledge can be considered in a variety of ways. Classifying knowledge helps organizations to identify the different types of knowledge with different nature that may need different procedures, tools and activities to process and manage (Tserng \& Lin, 2004; Lin et al., 2006). Hence, classifying knowledge is important to help the organizations to manage important the available knowledge resources successfully. (Tserng \& Lin, 2004; Lin et al., 2006)

\section{Types of Knowledge}

The most notable and important classification is two kinds of knowledge: tacit (or embodied) and explicit (or codified) Explicit knowledge is knowledge that can be documented, categorized, transmitted to others as information, and illustrated to others as through demonstrations, explanations and other forms of sharing. By contrast, tacit knowledge is knowledge which draws on the accumulated experience and learning of a person and which is hard to reproduce or share with others. (Bollinger \& Smith 2001).

\section{Explicit knowledge}

Explicit Knowledge can be expressed in formal and systematic language, and shared in the form of scientific formulae, specifications, manuals and such like. Explicit knowledge is easy to be captured, retrieved, 
shared and used because it can be Expressed in words and numbers that can be managed more easily. In project contexts, explicit knowledge may include project-related contents such as specifications, contracts, reports, drawings, changing orders and data (Lin et al., 2006). KLICON (1999) described explicit knowledge as being, ,readily available ${ }^{c e}$, recorded, codified and/or structured in a way that makes it easily transmissible and available to be retrieved and used, which can be found in a range of diverse sources, such as human resources data, meeting minutes and the Internet, (Klicon ,1999)

\section{Tacit knowledge}

Tacit knowledge is the most valuable type of content since it combines information with experiences, skills and understanding of people, which can help people to find best solutions and reduce opportunities of repeating mistakes. In project contexts, tacit knowledge may include work processes, problems faced, problems solved, expert suggestions, know-how, innovations and experiences (Lin et al., 2006).

\section{Knowledge Management}

The term "knowledge management" got recognition in the 1980s due to the emerging concerns of organizations regarding the increasing role of knowledge in organizational sustainability. Nonaka \& Takeuchi (1995) consider Knowledge Management as a form of management's expertise which draws out individual's tacit knowledge and makes it explicit and accessible for all employees to improve organizational performance. Davenport \& Prusak (2000), state that Knowledge Management "is managing the corporation's knowledge through a systematically and organizationally specified process for acquiring, organizing, sustaining, applying, sharing and renewing both the tacit and explicit knowledge of employees to enhance organizational performance and create value" (Davenport \& Prusak, 2000).

As a matter of fact, whether prepared or not, no nation can afford to 'delink' from global information connectivity and the knowledge economy. Countries like Pakistan have to take serious measures to convert conventional educational institutions into the key driver of knowledge economy. It is very important that teachers should be equipped with the knowledge and skills which are required to understand the challenges and opportunities of knowledge economy. The origin of this study is based on knowledge management practices of teachers at International Islamic University, Islamabad. In terms of definition of the concept, such researchers as Mertines et al. (2001) have taken an information systems approach, whereas others, such as Beijerse (2000) \& Newell, Robertson, Scarbrough \& Swan (2002) have taken a strategic approach. Whereas Skyrme (1999) \& Swan, Newell, Scarbrough \& Hislop (1999), among others, have taken a human resources 
process approach towards definition of knowledge management. (Skyrme, 1999).

\section{Knowledge management practices}

Practices refer to the way ideas are translated into action in the process of accomplishing job functions. KM practices include the understanding of knowledge management: knowledge generation, knowledge acquisition, knowledge organization, knowledge storage, knowledge transfer, knowledge sharing, and knowledge retention (Daud, Rahim \& Alimun, 2008). Advantages of using KM practices include the fact that they help organizations to refocus on using their already existing knowledge, they create the environment for innovation rather than limiting themselves to best practices solutions only, they enable convergence towards knowledge portals rather than separate silos of knowledge in an organization, and they promote interconnectedness among departments, employees, and systems in an organization. Kidwell, Vander Linde and Johnson (2000) suggest that in an academic institution, knowledge management practices "can lead to better decision-making capabilities, reduced "product" development cycle time (for example, curriculum development and research), improved academic and administrative services, and reduced costs".

\section{Knowledge management practices tools and techniques}

Following are some most popular tools for knowledge management, which are being widely used by many organizations.

\section{a. Brainstorming}

Brainstorming is a simple way of helping a group of people to generate new and unusual ideas. Brainstorming is useful when there is a need to generate a relatively large number of options or ideas.

\section{b. Mentor / Mentee Scheme}

Mentoring is a work relationship between a senior and junior organizational member with an intentional agenda designed to transfer experience and learning. The mentor has experience and seniority in the organization, and personally advises, counsels, coaches, and promotes the career development of the mentee. Mentoring is a form of knowledge sharing. It builds a caring, trusting culture.

\section{c. Peer Assist}

This technique used by a team to get assistance from peers and subject matter experts regarding a significant issue the teams are facing. The purpose of a Peer Assist is to shorten the learning curve of the project team. 


\section{d. Storytelling}

Storytelling is conveying of events in words, images, and sounds a powerful way to share and transfer knowledge, especially experiential and tacit knowledge. It is literally about telling a story: a person who has valuable knowledge tells stories of his/her experience in front of people who want to gain knowledge.

\section{e. Communities of Practice}

Communities of Practice (COPs) are groups of people who share a concern or a passion for something they do, and learn how to do it better as they interact regularly. In the context of KM, COPs are formed-intentionally or spontaneously - to share and create common skills, knowledge, and expertise among employees.

\section{f. Document Management System}

Maintaining a 'document repository' with good categorization and/or taxonomy and metadata (link to these later) is paramount to filing and, subsequently, searching and finding the right information at the right time.

\section{g. Social Network Services}

A social network is a group of people who share a common area of interest. Social network services are online systems that support social networking. The core services they offer usually include finding people who have similar interests or needs; Aggregating people into groups, or subgroups, and being able to communicate with those groups; and Sharing content, such as documents links to relevant websites, or even streaming video.

\section{h. Knowledge Mapping}

Knowledge Mapping is a process by which organizations can identify and categorize knowledge assets within their organization, people, processes, content, and technology.

\section{Objectives of the Study}

1. To explore the existing knowledge management practices of teachers in International Islamic University, Islamabad.

2. To find out the difficulties regarding Knowledge Management practices in International Islamic University, Islamabad.

\section{Research Questions}

The study will be based on the following research questions.

1. How do knowledge management practices exists in International Islamic University, Islamabad?

2. How do teachers face difficulties during teaching learning process regarding knowledge management? 


\section{Research design}

Qualitative method approach was used in conducting research. Qualitative data were analyzed to meet the objectives of the study. The researcher personally collected the data through the Interview guide.

\section{Data analysis and interpretation}

Data were collected, analyzed and interpreted. Percentage was used to analyze the data.

\section{Table 4.1: "Brain storming".}

The percentage of teachers responded to each item under the question, "How do you Brainstorm to generate relatively large number of options and unusual ideas to find the solution of problems"? And the responses were tabulated below.

S. \#

$$
\begin{aligned}
& 2 \\
& 3 \\
& 4
\end{aligned}
$$

Using sticky notes

A flip chart

A piece of paper

All of the above

Total frequency

5

6

14

15

40
Percentage

12.5

100

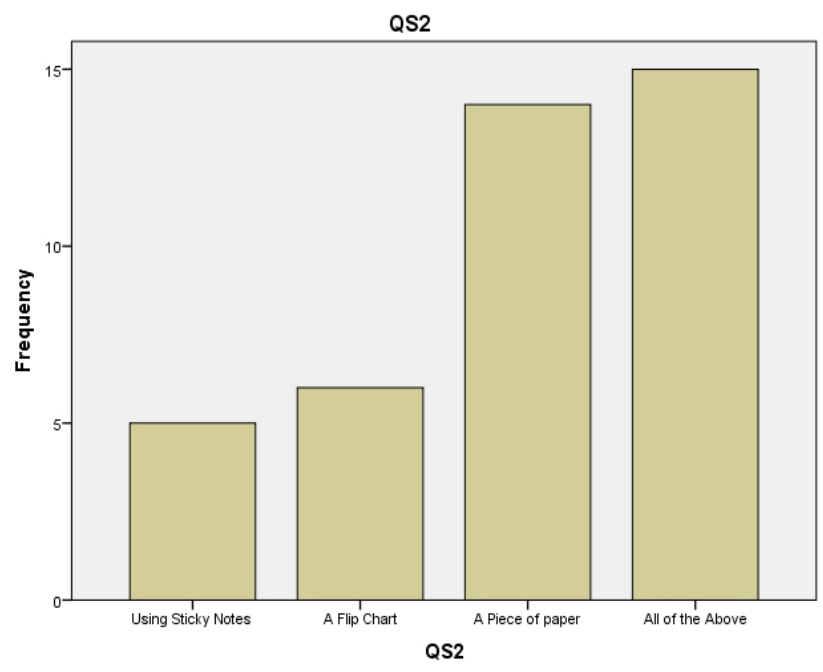

Figure 4.1: "Brain storming".

The data tabulated in table 4.1 shows that $12.5 \%$ participants responded to the statement "Using sticky notes", $15.0 \%$ participants responded to the statement "A flip chart", 35.0\% participants' responded to the statement "A piece of paper" and 37.5\% participants responded to the statement "All of the above". So, the above responses show that majority of participants were using several brainstorming techniques. 


\section{"Employee turnover".}

The percentage of teachers responded to each item under the question, "A lot of tacit Knowledge loss due to high employee turnover"? And the responses were tabulated below.

S. \#

$$
\text { Items }
$$

Agree

2

Total frequency

29

6

5

40
Percentage

72.5

15.0

12.5

100

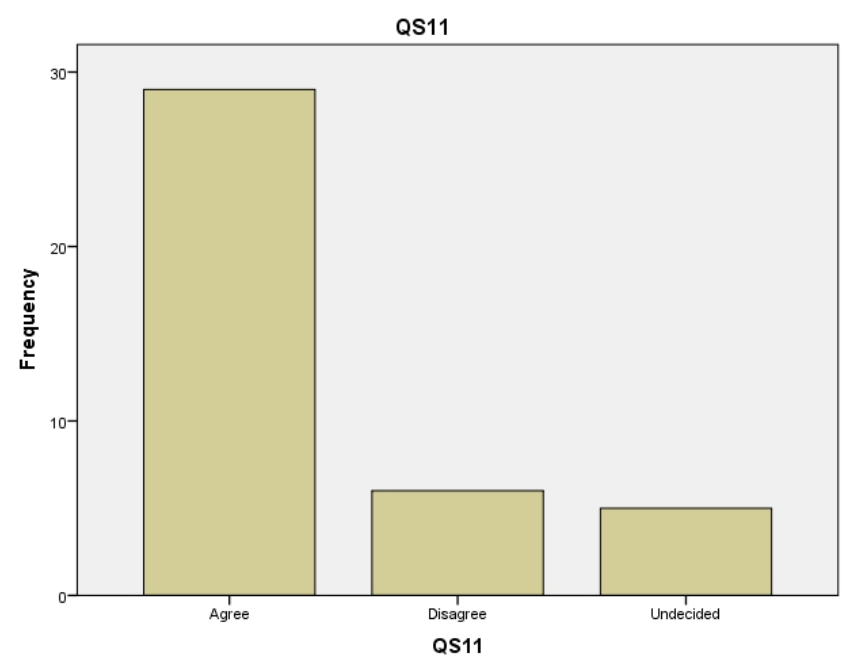

Figure 4.2: "Employee turnover".

The data tabulated in table 4.2 shows that $72.5 \%$ participants responded to Agree statement, $15.0 \%$ participants responded to Disagree statement and $12.5 \%$ participants' responded to Undecided statement. So, the opinion of respondents was inclined towards agreement with the above statement.

\section{Conclusion}

Based on findings, it also revealed that teachers agree on sharing and transferring knowledge either externally or internally in order to gather new knowledge. Nevertheless, this transferring process will consider successful approach if teachers prepared to share and use them in their teaching process (Amin, 2005). Most teachers were aware of the concept of Knowledge Management and using brainstorming to find solution of issues. Most of the teachers were in view that a lot of tacit Knowledge loss due to high employee turnover. 


\section{References:}

Alavi, M. \& Leidner, D.E. (2001). "Review: knowledge management and knowledge management systems: conceptual foundations and research issues", MIS Quarterly, Vol. 25, pp. 107 - 136.

Dalkir, K. (2005). Knowledge management in theory and practice, Boston, MA:

Elsevier.

Davenport, T. H., \& Prusak, L. (2000). Working Knowledge: How organizations manage what they know, Boston, MA: Harvard Business School Press.

Kidwell, J., et al. (2000). Applying Corporate Knowledge Management Practices in Higher Education. EDUCAUSE Leadership, 4(3). Retrieved on 23rd March 2012.http://net.educause.edu

Nonaka, I.\& Takeuchi, H. (1995). The knowledge-creating company: How Japanese companies create the dynamics of innovation, Oxford, UK: Oxford University Press.

Skyrme, D. J. (1999). Knowledge Networking: Creating a Collaborating Enterprise, Butterworth, Oxford.

Swan, J., Newell, S., Scarbrough, H. \& Hislop, D. (1999) Knowledge management and innovation: Networks and networking, Journal of Knowledge Management, 3(4), pp. 262-275.

Rowley, J. (2002). Using Case Studies in Research. Management Research News, 25(1), 16-27. Retrieved on 10th June 2012.www.emeraldinsight.com 